\title{
Strengthening Historical Awareness Through Learning Based on Tourism Work of Hindu-Buddhist Historical Sites in Tulungagung
}

\author{
Danan Tricahyono \\ Universitas Sebelas Maret \\ danancahyono2@gmail.com
}

\section{Article History}

accepted 1/09/2020

approved 4/10/2020

published 1/12/2020

\begin{abstract}
The purpose of learning history is to make students have historical thinking skills. To achieve historical thinking skills, students need to be equipped with capital to have historical awareness. One of the efforts to instill historical awareness can be done by learning field trip. Field trip implementation by inviting students to visit historical sites. Objects that are used as tourism objects are Hindu-Buddhist sites in Tulungagung. The site is in the form of ancient caves and temples. The purpose of this paper is to provide alternative conceptual ideas for history teachers to strengthen historical awareness through the field trip method. Through well-packaged learning activities, it can provide direct experience for participants to get closer to historical sites. From each site visited there is a story and a red thread will be found in the narrative of the relationship between history and the local context and national history. So that it will lead to an appreciation of the meaning and essence of history that is used for guidance in the present and future life.

Keywords: Historical awareness, field trip, Hindu-Buddhist sites
\end{abstract}

\begin{abstract}
Abstrak
Tujuan dari pembelajaran sejarah menjadikan siswa memiliki keterampilan berpikir historis. Guna mencapai keterampilan berpikir historis siswa perlu dibekali modal untuk memiliki kesadaran sejarah. Salah satu upaya untuk menanamkan kesadaran sejarah dapat dilakukan dengan pembelajaran karya wisata. Pembelajaran karya wisata implementasinya dengan mengajak peserta didik berkunjung ke situs-situs sejarah. Objek yang dijadikan karya wisata berupa situssitus Hindu-Budha di Tulungagung. Situs tersebut berupa goa purbakala dan candi. Tujuan penulisan ini memberikan gagasan konseptual alternatif bagi guru sejarah dalam rangka penguatan kesadaran sejarah melalui metode karya wisata. Melalui kegiatan pembelajaran yang dikemas dengan baik dapat memberikan pengalaman langsung kepada peserta untuk lebih dekat dengan situs-situs sejarah. Dari setiap situs yang dikunjungi terdapat kisah dan akan ditemukan benang merah narasi hubungan sejarah dengan konteks lokal dengan sejarah nasional. Sehingga akan memunculkan penghayatan terhadap makna dan hakekat sejarah yang digunakan untuk pedoman di kehidupan sekarang dan masa yang akan datang.
\end{abstract}

Kata kunci: Kesadaran sejarah, karya wisata, situs Hindu-Budha

\footnotetext{
Social, Humanities, and Education Studies (SHEs): Conference Series https://jurnal.uns.ac.id/shes 


\section{Pendahuluan}

Pelajaran sejarah Indonesia memiliki beberapa tujuan mulai dari membangun kesadaran peserta didik tentang konsep waktu dan tempat dalam rangka memahami perubahan dan kesinambungan sejarah Indonesia, menumbuhkan apresiasi dan penghargaan terhadap peninggalan sejarah sebagai bukti peradaban Indonesia, menumbuhkan pemahaman peserta didik terhadap diri sendiri, masyarakat dan proses terbentuknya bangsa Indonesia yang memiliki rasa bangga dan cinta tanah air, melahirkan empati dan perilaku toleran yang dapat diimplementasikan dalam berbagai bidang kehidupan masyarakat dan bangsa mengembangkan kemampuan berpikir historis yang menjadi dasar untuk berpikir logis, kreatif, inspiratif dan inovatif (Agung, 2015), (Tricahyono and Widiadi 2020). Guna menjadikan peserta didik bisa menjadikan pemikir sejarah maka modalnya harus dibekali dengan kesadaran sejarah.

Kesadaran sejarah merupakan kondisi psikologis seseorang dalam rangka melakukan penghayatan akan makna dari peristiwa sejarah dan dimensi kontinuitas yaitu perubahan dari masa kini ke masa depan (Kartodirjo, 2016). Jadi kesadaran sejarah berhubungan dengan jiwa peserta didik. Untuk mengukur kesadaran sejarah peserta didik dapat dinilai dari sikapnya. Hal ini tidak lepas dari sikap seseorang dipengaruhi oleh kondisi kejiwaanya. Sehingga pembelajar sejarah yang memiliki kesadaran sejarah akan berpegang teguh pada nilai-nilai positif yang diwariskan peristiwa sejarah. Dalam prakteknya pada pembelajaran sejarah belum semua peserta didik mampu mencapai kesadaran sejarah.

Bukti yang menunjukan jika kesadaran sejarah para peserta didik masih kurang dapat dilihat dari beberapa indikator kesadaran sejarah seperti pemaknaan terhadap peristiwa (Aisiah, Suhartono, \& Sumarno, 2016). Penjabaran dari indikator kesadaran sejarah tersebut berkenaan dengan menemukan dampak positif dan negatif serta nilainilai positif dari peristiwa sejarah. Wujud dari kesadaran tersebut dapat dilihat dari sikap kecintaanya terhadap tanah air Indonesia berupa rasa nasionalisme dan patriotisme. Contohnya masih ditemuinya beberapa peserta didik yang kurang disiplin ketika mengikuti upacara bendera. Terdapat peserta didik yang belum semuanya bersikap sempurna. Apabila mereka memiliki kesadaran sejarah pasti akan mengerti jika upacara bendera berhubungan dengan kemerdekaan Indonesia.

Indikator yang kedua, berhubungan dengan pengetahuan peserta didik terkait peristiwa sejarah (Aisiah et al., 2016). Beberapa sikap yang kurang menunjukan terkait kesadaran sejarah tersebut diantaranya ketidaktahuan peserta didik terhadap nilai-nilai historis dari situs-situs sejarah yang berada di lingkup lokal. Ketidaktahuan tersebut akan berdampak pada sikap cenderung tidak peduli terhadap benda-benda bernilai historis sehingga akan memunculkan sikap kurangnya rasa memiliki terhadap situs sejarah, hal ini dapat dilihat dari sikap para pelajar ketika berkunjung ke situs hanya berburu tempat untuk foto dan acuh terhadap aturan-aturan yang harus dipenuhi, adanya yang lebih memprihantinkan yaitu masih ditemui para peserta didik yang bertindak vandalis terhadap benda cagar budaya.

Adanya masalah terkait kurangnya kesadaran sejarah perlu diberikan alternatif solusi untuk memupuk dan mengembangkan kesadaran sejarah para peserta didik. Salah satu caranya dengan menerapkan pembelajaran sejarah berbasis karya wisata sejarah. Implementasi dari pembelajaran karya wisata dengan cara mengajak para peserta didik untuk mengunjungi situs-situs sejarah. Situs sejarah yang dijadikan objek kunjungan mulai dari masa pra-aksara sampai dengan kontemporer. Pada artikel ini menulis memberikan alternatif untuk mengunjungi situs-situs sejarah yang berada di lingkup lokal. Pertimbangan tersebut diambil karena situs yang berada di sekitar lebih mudah di jangkau sehingga memiliki efisiensi dari segi biaya. Selain itu juga situs-situs sejarah lokal memiliki kontribusi besar untuk menambah khasanah pengetahuan sejarah di nasional. 
Penulis memberikan contoh untuk memanfaatkan situs-situs sejarah yang berada di Kabupaten Tulungagung untuk dijadikan objek sebagai pembelajaran karya wisata. Para guru dapat mengunjungi situs antara lain: Candi Gayatri, Candi Sanggrahan, Goa Selomangleng, dan Candi Mirigambar. Secara geografis lokasi situs tersebut tidak jauh dari pusat kota sehingga memungkinkan para siswa yang bersekolah sekitar di kota memiliki jarak yang dekat untuk mengunjunginya. Masing-masing situs tersebut memiliki narasi sejarah unik dan bernilai sehingga patut untuk dipelajari serta diwariskan kepada generasi sekarang terutama tentang keberadaan Tulungagung tempo dulu dalam hubungannya dan peranannya dengan sejarah nasional Indonesia. Berdasarkan uraian tersebut penulis tertarik untuk memberikan gagasan konseptual dengan mengambil topik pembelajaran karya wisata sejarah situs Hindu-Budha di Tulungagung sebagai upaya penguatan kesadaran sejarah pesera didik.

\section{Pembelajaran Karya Wisata Sejarah}

Pembelajaran karya wisata memiliki pengertian metode pembelajaran yang mengajak peserta didik untuk melaksanakan proses pembelajaran di luar kelas (Sudjana, 2011). Fokus dari karya wisata dengan mengajak peserta didik mengunjungi suatu tempat yang ada kaitanya dengan materi di sekolah. Pendapat tersebut diperkuat oleh (Darajat, 2001) yang menguraikan bahwa pembelajaran karya wisata merupakan kunjungan ke sebuah tempat yang berada di luar ruang kelas sebagai kegiatan yang memiliki hubungan akademis dalam rangka mencapai tujuan pembelajaran dan pendidikan. Objek yang dijadikan kunjungan sangat beraneka ragam, bergantung pada tujuan materi pembelajarannya. Untuk karya wisata sejarah merupakan metode pembelajaran yang mengajak peserta didik mengujungi tempat-tempat bersejarah. Pada umumnya objek-objek yang dijadikan karya wisata sejarah mulai situs-situs peninggalan masa pra-aksara, kompleks percandian, makam kuno, masjid kuno, bangunan indis, museum.

Tujuan dan fungsi dari pembelajaran karya wisata sejarah sangat beragam. Pertama, memberikan pengalaman langsung kepada peserta didik terkait dengan teori yang didapat di kelas untuk dielaborasikan dengan objek sejarah yang dilihatnya. Kedua, membangkitkan minat dan perhatian sekaligus menghilangkan rasa kejenuhan pembelajaran di kelas. Ketiga, menumbuhkan dan mengembangkan sikap apresiatif peserta didik terhadap warisan-warisan sejarah. Keempat, mendapat keteranganketerangan baru dari hasil kunjungan ke objek sejarah tertentu. Sementara manfaat yang akan diperoleh dari pembelajaran karya wisata sejarah adalah menumbuhkan dan mengembangan aspek psikomotorik dan afektif para peserta didik. Mengingat pembelajaran karya wisata sejarah menunutut keaktifan para peserta didik untuk berpartisipasi mengikuti rangkaian kunjungan ke objek-objek sejarah. Dari kunjungan tersebut akan memunculkan kesadaran sehingga akan tumbuh sikap lebih menghargai warisan masa lalu untuk tetap dijaga dan dilestarikan untuk generasi yang akan datang. Langkah-langkah pembelajaran karya wisata dapat dibagi menjadi tiga yaitu persiapan, pelaksanaan, dan evaluasi (Safitri, 2018). Pertama, tahap persiapan. Pada tahap ini dirumuskan tujuan beserta luaran diadakanya karya wisata sejarah, menentukan objek-objek

sejarah mana saja yang akan dikunjungi, menyusun jadwal kunjungan sekaligus jalanya kegiatan, membagi peserta didik jika diperlukan untuk mempermudah pengkondisian di lapangan, dan menyusun tata tertib yang harus dipatuhi peserta didik selama mengikuti pembelajaran karya wisata sejarah. Kedua, tahap pelaksanaan. Tahap ini fokus pada kegiatan pembelajaran selama berada di objek kunjungan. Pendekatan pembelajaran yang bisa dipilih ada dua yaitu pembelajaran yang terpusat pada guru atau atau terpusat pada peserta didik. Apabila pembelajaran terpusat pada guru sebisa mungkin guru harus bisa berperan sebagai guide yang memandu sekaligus memberikan informasi kepada para peserta didik. Apabila pembelajaran berpusat pada peserta didik guru hanya sebagai fasilitator yang bertugas mengawasi 
kinerja, memberikan bimbingan kepada peserta didik. Untuk peserta didik secara aktif melakukan pencatatan setiap informasi guna melengkapi pengetahuan yang telah diperoleh dari kelas. Ketiga, tahap evaluasi. Tahap ini berisi refleksi dari serangkaian kegiatan yang telah terselenggara. Para peserta didik diberikan kesempatan untuk mengevaluasi sementara guru berperan untuk memberikan penguatan.

\section{Implementasi Pembelajaran Karya Wisata Sejarah untuk Penguatan Kesadaran Sejarah}

Penerapan pembelajaran karya wisata sejarah memiliki potensi sebagai upaya untuk penguatan kesadaran sejarah peserta didik. Dengan menggunakan pendekatan student oriented peserta didik akan lebih aktif melakukan penggalian informasi terhadap objek-objek yang dijadikan kunjungan. Objek yang dipilih untuk dijadikan kunjungan adalah beberapa situs Hindu-Budha yang berada di Kabupaten Tulungagung. Penetapan situs yang akan dijadikan kunjungan memperhatikan faktor keterjangkauan sekolah dengan situs. Untuk sekolah yang berada di kawasan Kecamatan Boyolangu bisa mengunjungi Candi Gayatri, Candi Sanggrahan, dan Goa Selomangleng. Ketiga situs tersebut berlokasi di kawasan sekitar Gunung Kapur yang masuk administrasi Kecamatan Boyolangu. Untuk sekolah di kawasan timur Kabupaten Tulungagung (Kecamatan Ngunut dan Kecamatan Sumbergempol) dapat mengunjungi Candi Mirigambar yang berlokasi di Desa Mirigambar, Kecamatan Sumbergempol. Hal mendasar dari pemanfaatan situs lokal sebagai sumber pembelajaran akan memberikan kontribusi untuk memperkaya materi sejarah Hindu-Budha pada mata pelajaran sejarah kelas X pada Kompetensi Dasar (KD) 3.6 Menganalisis perkembangan kehidupan masyarakat, pemerintahan, dan budaya pada masa kerajaankerajaan Hindu dan Buddha di Indonesia serta menunjukkan contoh bukti-bukti yang masih berlaku pada kehidupan masyarakat Indonesia masa kini. Khususnya pada materi bukti-bukti kehidupan pengaruh Hindu dan Buddha yang masih ada sampai masa kini.

Penulis akan menguraikan teknis pembelajaran karya wisata sejarah ke salah satu situs yaitu Candi Mirigambar. Sementara untuk uraian ke situs yang lainnya hampir sama dari segi tekniksnya hanya berbeda pada sisi muatan materi. Pembelajaran karya wisata sejarah dari alur pembelajarannya dimulai dengan menentukan alokasi waktu yang akan digunakan untuk kunjungan. Waktu yang digunakan sekitar dua jam pelajaran atau sekitar 90 menit. Waktu tersebut digunakan untuk mengecek kehadiran peserta didik, barang bawaan peserta didik, menegaskan tujuan pembelajaran yaitu mengetahui dan menganalisis keberadaan Candi Mirigambar, dan tata tertib selama berada di lokasi. Teknis saat tiba di lokasi memberikan kesempatan kepada semua peserta didik untuk melakukan pengamatan secara seksama terhadap struktur bangunan candi sekaligus melakukan pencatatan. Ketika proses pengamatan telah selesai guru mengajak peserta didik untuk membentuk lingkaran. Pada tahap ini guru mengajak diskusi kepada peserta didik. Salah satu dari peserta didik diberikan kesempatan untuk mempresentasikan hasil pengamatannya. Guru juga mempersilahkan kepada peserta didik lainnya untuk memberikan tanggapan ataupun menambahkan informasi.

Pada sesi akhir guru memberikan poin-poin penting materi dan memberikan penguatan pentingnya peserta didik untuk memiliki kesadaran sejarah. Dalam kaitannya dengan Candi Mirigambar kepada peserta didik guru memulai menjelaskan tentang angka tahun yang terletak di balok-balok batu yaitu adanya pahatan angka 1214 Saka (1282 M), 1310 Saka (1388 M) dan 1321 saka (1399 M) (Sedyawati et al., 2013). Angka tahun tersebut menunjukan kemungkinan Candi Mirigambar mulai dibangun. Mengenai fungsi dari candi belum ada sumber yang menjelaskan. Penekanan aspek waktu menjadi penting dalam sejarah. Pentingnya memahami angka tahun terkait indikator kesadaran sejarah aspek pengetahuan dari peristiwa sejarah. Jadi modal dasar untuk memiliki kesadaran sejarah peserta didik mampu memahami apa,siapa, kapan, dimana dan mengapa peristiwa sejarah tersebut terjadi (Aisiah et al., 2016). 
Guru juga diharuskan untuk menunjukan sisi keunikan dari Candi Mirigambar berupa panil relief yang dipahatkan pada dinding candi. Pada relief Candi Mirigambar terdapat kisah Panji. (Kieven, 2017) menjelaskan bahwa cerita panji mengandung aspek simbolis majemuk. Apabila digeneralisir kisah panji berisi tentang perjalanan asmara Pangeran Panji dari Jenggala dan Putri Candrakirana dari Daha (Kediri), mereka bertunangan, lalu terpisahkan. Melalui pencarian yang panjang diantara mereka dan sesudah Panji berjuang melalui banyak peperangan, diantara mereka berdua dapat mengatasi banyak halangan barulah dapat bertemu dan menikah. Dari kisah Panji apabila diambil benang merahnya terdapat indikator kesadaran sejarah tentang kegunaan sejarah yaitu aspek inspirational. Kisah Panji memberikan inspirasi nilai kehidupan yang dapat diambil oleh para peserta didik tentang jiwa petualangnya, senang mencoba hal baru dan sosok pekerja keras dalam menggapai tujuan. Daya kreatif untuk mengemas pembelajaran sejarah dengan materi yang usang menjadi lebih bernilai memang menjadi sebuah tantangan tersendiri bagi para guru supaya pembelajaran sejarah banyak diminati.

Nilai-nilai kehidupan yang diambil dari peristiwa sejarah berhubungan dengan fungsi atau sasaran pembelajaran sejarah. (Kochar, 2008) menjelaskan jika sasaran dari pembelajaran sejarah salah satunya mengajarkan tentang prinsip-prinsip moral. Prinsip tersebut memua dua hal yaitu baik dan buruk, benar dan salah sebagaimana peristiwa sejarah yang didalamnya memuat hal tersebut. Prinsip-prinsip moral dapat lebih mudah disimpan di hati peserta didik apabila diajarkan melalui contoh-contoh dan cerita. Dengan demikian materi sejarah dengan lingkup khususnya di Tulungagung merupakan sebuah keharusan untuk diberikan sebagai materi pembelajaran kepada peserta didik. Penyampaian materi sejarah di tingkat lokal akan menjadikan siswa mengerti akan makna dari peristiwa dan kritis terhadap masa lalu sehingga akan timbul perubahanperubahan pada diri siswa berupa muncul dan semakin kuatnya kesadaran sejarah.

\section{KESIMPULAN}

Pembelajaran karya wisata sejarah sebagai sarana penguatan kesadaran sejarah menjadi sebuah keharusan bagi guru-guru sejarah untuk diterapkan. Kesadaran sejarah menjadi modal dasar bagi siswa untuk menjadi siswa yang memiliki kemampun berpikir historis yang menjadi dasar untuk berpikir logis, kreatif, inovatif, dan inspiratif sehingga akan membentuk sikap peserta didik yang selalu mendasarkan pada nilai dan norma yang mencerminkan karakter diri, masyarakat dan bangsa.

\section{DAFTAR PUSTAKA}

Agung, L. (2015). Sejarah Kurikulum Sekolah Menengah Di Indonesia: Sejak Kemerdekaan Hingga Reformasi. Yogyakarta: Ombak.

Aisiah, Suhartono, \& Sumarno. (2016). The Maesurement Model Of Historical Awareness. Research and Evaluation in Education, 2(2), 108-121.

Darajat, Z. (2001). Metodik Khusus Pengajaran Agama Islam. Jakarta: Bumi Aksara.

Kartodirjo, S. (2016). Pendekatan IImu Sosial Dalam Metodologi Sejarah (2nd ed.). Yogyakarta: Ombak.

Kieven, L. (2017). Menelusuri Panji Di Candi-Candi: Relief Figur Bertopi di Candi-Candi Zaman Majapahit. Jakarta: KPG.

Kochar, S. . (2008). Teaching of History. Jakarta: Grasindo.

Safitri, A. (2018). Efektivitas Penggunaan Metode Field Trip Terhadap Hasil Belajar 
Sejarah SMAN 6 Pontianak.

Sedyawati, E., Santiko, H., Djafar, H., Maulana, R., Ramelan, W., \& Ashari, C. (2013). Candi Indonesia: Seri Jawa (First). Jakarta: Direktorat Pelestarian Cagar Budaya dan Permuseuman, Direktorat Jendral Kebudayaan, Kementerian Pendidikan dan Kebudayaan.

Sudjana, N. (2011). Dasar-Dasar Proses Belajar Mengajar. Bandung: Sinar Baru Algesindo.

Tricahyono, D., \& Widiadi, A. N. (2020). Upaya Meningkatkan Kemampuan Berpikir Historis Melalui Penerapan Model Pembelajaran Resource Based Learning Di SMA Trenggalek. Agastya: Jurnal Sejarah Dan Pembelajarannya, 10(2), 208-221. https://doi.org/http://doi.org/10.25273/ajsp.v10i2.6462 